Article

\title{
Is Southern Xinjiang Really Unsafe?
}

\author{
Feng $\mathrm{Xu}^{1}{ }^{1}$, Xuejiao Lin ${ }^{1}$, Shuaishuai $\mathrm{Li}^{2,3, * \mathbb{C}}$ and Wenxia Niu ${ }^{1}$ \\ 1 School of Management, Shandong University, Jinan 250100, China; tourism@sdu.edu.cn (F.X.); \\ linxuejiao@mail.sdu.edu.cn (X.L.); 201712739@mail.sdu.edu.cn (W.N.) \\ 2 School of Government, Peking University, Beijing 100871, China \\ 3 The Center for Spatial Data Science, The University of Chicago, Chicago, IL 60615, USA \\ * Correspondence: lukali@pku.edu.cn; Tel.: +1-773-690-0060
}

Received: 27 November 2018; Accepted: 5 December 2018; Published: 6 December 2018

check for updates

\begin{abstract}
Destination image and safety not only affect tourist decision-making but also the sustainable development of tourist destinations. Some tourist destinations are too vulnerable to defend against emergency tourist crises, and tourists' perceived safety can be severely biased, which is then deepened by media panic caused by the publication of excessive negative reports. This paper discusses the mechanism of perceived safety and perceived image on tourist behavioral intention, as well as the inter-group difference. Our study is based on a survey in Southern Xinjiang in which the respondents were divided into four groups. Four structural equation models were established with "perceived safety" and "perceived image" as independent variables, "destination trust" and "perceived value" as mediating variables, and "behavioral intention" as the dependent variable. The final results show that a paradox of safety perception exists in tourists' perception of Southern Xinjiang. The perceived safety differs sharply between the tourists who have traveled to Southern Xinjiang and those who have not. The mechanism of perceived safety on tourist behavioral intention differs from that of the perceived image on tourist behavioral intention. Destination image still plays a key role in tourist traveling decision-making. The findings are of great significance for the restoration of cognitive bias, management, and marketing activities, and the sustainable development in Southern Xinjiang and similar destinations.
\end{abstract}

Keywords: Southern Xinjiang; perceived safety; perceived image; cognitive bias

\section{Introduction}

Tourist destination image and safety are key factors affecting tourist decision-making and the sustainable development of the destination [1-4]. However, the interactions between the two factors on tourist decision-making processes are different. Image, which can reflect the tourism value of a destination, serves as the fundamental motive for tourists' decision-making, whereas safety is the basic guarantee for the sustainable development of the destination and a requirement for tourists' decision-making. The perceived image represents strong stabilities of value, which is reflected not only in tourists' overall perception of the tourism resource endowment, tourism service level, and social and cultural environment of the destination, but also in tourists' emotional attachment to the destination. Such emotional attachments are bridges connecting the destination with tourists $[5,6]$. Perceived safety is the subjective judgment of tourists of the safety situation of the destination [7]. There may be a discrepancy between tourists' subjective judgment of safety and the objective situation of the destination due to information asymmetry, tourists' cognitive bias, and their vulnerable perception of safety. Once such a discrepancy has formed, it seems hard to repair [8-10]. In a society with highly-developed social media, excessively negative news reports easily lead to media panic. So, any crisis in a tourist destination is often reported to be more severe compared to reality, which magnifies 
the safety perception problems of the destination and aggravates tourists' safety cognitive bias [11,12]. Managers need to market more effectively, and improve the bias of tourists' perceived safety, in order to ensure the sustainable development of destinations.

Many countries and regions have been shrouded in the shadow of terrorism, and frequent crisis events have seriously affected their vulnerable tourism industry. Terrorist attacks have had an ever increasing impact on the tourism industry, such as the events of 11 September 2001 in New York, the 5 July 2009 terrorist attacks in Xinjiang province, and the terrorist attacks in Paris in 2015. Determining how to eliminate the adverse effects of these crisis events has become a common issue for tourist destinations.

The impact of crisis events in developing regions is more lasting and difficult to recover from when compared with comparable events which occur in more developed regions [13]. Crisis events have almost completely depressed tourism in some developing regions. For instance, terrorist incidents resulted in the decline in tourism in Xinjiang in 2014 [14]. The image of tourism safety in Xinjiang was severely damaged, resulting in tourists' bias about the safety problems in Xinjiang. Being sparsely populated and covering a vast area, Xinjiang is more than $1,660,000 \mathrm{~km}^{2}$, amounting to one-sixth of the total area of China, which is a reason for the lack of communication between different regions of Xinjiang. The primary victims in the most violent terrorist attacks are people from Southern Xinjiang. Thus, cognitive bias about the safety of Southern Xinjiang exists in different regions of Xinjiang: people in the more developed regions of Northern Xinjiang tend to consider that Southern Xinjiang is less safe than Northern Xinjiang [15]. However, tourists from other regions of China who have actually visited Southern Xinjiang give a generally positive evaluation of its safety [15].

How did this contradictory belief occur? What causes such cognitive bias on tourism safety? How can the perceived safety and perceived image affect tourist behavioral intention? To answer these questions, with "perceived safety" and "perceived image" as independent variables, "trust" and "perceived value" as mediating variables, "behavioral intention" as a dependent variable, we divided the survey respondents into four groups: in-transit tourists in Southern Xinjiang (group 1), tourists who have traveled to Southern Xinjiang (group 2), non-Xinjiang tourists without experience in Southern Xinjiang (group 3), and Northern Xinjiang tourists without experience in Southern Xinjiang (group 4). Based on this, we focused on the mechanism of perceived safety and perceived image on tourist behavioral intention and the inter-group difference. We provide several conclusions, including that a paradox of safety perception exists in tourists' perception of Southern Xinjiang. These results are important for the elimination of cognitive bias towards Southern Xinjiang and similar areas in the aspects of the management, marketing, and the sustainable development of destinations.

\section{Literature Review}

\subsection{Perceived Safety}

Perceived safety is an individual's subjective perception of the safety situation in the world and their premonition of potential danger or risk [16]. In the field of research on tourism safety, perceived safety refers to tourists' subjective feeling of the safety situation of the destination [17-19]. Numerous studies have shown that tourists' perceived safety of a destination significantly impacts on their decision-making [20-22]. In many destinations, the real risk has a limited impact, whereas tourists' subjective perceived safety plays a dominant role in the process of their decision-making [7,23-25]. Sonmez and Graefe found that perceived safety can influence tourists' decision-making by influencing their intention to travel [23]. As the safety status of most destinations poses a rather limited threat to tourists, perceived safety was regarded as a dimension of perceived image in some papers. However, the tourist destinations beset by potential risks cannot be measured accurately through a single dimension. Also, it is difficult to clarify the role of perceived safety in the sustainable development of a destination. Therefore, perceived safety should be considered as an independent variable in the study of such destinations [12]. In most cases, tourists' perceived safety acts as the prime motivator. 
Tourists will avoid destinations with severe safety issues, no matter how many resources are available, which directly affects the sustainable development of the destinations [18,26,27].

Over time, tourist's cognitive bias still exists, which affects their traveling decision-making, as they tend to avoid risks, even after the safety situation has improved [28]. The cognitive bias often differs in different groups, influenced by some factors such as personal information processing ability, cost of access to information, and propaganda in the media $[17,21]$. Some groups' perceived safety may be close to the real situation, whereas others' may deviate from it. Tourists who have been to a certain destination may have better safety perception than those who have never been $[29,30]$. Therefore, the following hypothesis is proposed:

Hypothesis 1 (H1). Tourists' perceived safety of Southern Xinjiang differs in different groups. Tourists in Southern Xinjiang (group 1) and tourists with experience traveling to Southern Xinjiang (group 2) provide a better safety evaluation than those without such experience (groups 3 and 4).

\subsection{Perceived Image}

The perceived image of the destination reflects tourists' comprehensive feelings towards the elements of the destination $[5,6]$, as well as the value judgment of the destination. Perceived safety has received increasing attention since being introduced into tourism studies in the 1970s [12,31-33]. With the deepening of study in this field, perceived safety has been shown to be multidimensional [34-37]. Cognitive image and emotional image are deemed the most important components of destination image. Cognitive Image is the production of tourists' processing of destination information [38], which reveals the functional characteristics of the destination.

Related research mainly focuses on the objective contents of destinations, such as the natural environment, cultural resources, social environment, tourism products and services, and tourism infrastructure [39-41]. The use of multi-dimensions is of great value for further study of the mechanism of different dimensions of the destination image, but it is not conducive to the comprehensive study of perceived image [42]. Therefore, many scholars chose emotional image to study perceived image [43,44]. Emotional image is tourists' emotional response to various attributes of the destination [45-47]. Numerous scholars think that emotional image better reflects tourists' perception of the destination image, which facilitates comprehensive research on the perceived image $[43,48,49]$. Hence, we chose the emotional image dimension of perceived image to establish models.

\subsection{Trust}

Trust is a psychological state wherein individuals accept vulnerability based on their positive expectations of the behavioral consequences. Trust is often subject to certain risks, and the results of trust, in turn, react to trust behaviors $[50,51]$. Therefore, trust plays a decisive role when individuals face risk choices [52,53]. Tourists' trust in a destination refers to their emotional attachment to the destination and their belief that the destination is consistent with its propaganda [54]. Trust determines the sustainable development of the destination. Maintaining trust between tourists and destinations helps establish a good relationship between them, and then improves tourists' loyalty [41,55].

\subsection{Perceived Value}

Perceived value is tourists' subjective judgment after comparing the perceived costs and perceived benefits of destinations [56-58]. The aim is to achieve a balance between tourists' "pay" and "receive" [59,60]. Specifically, perceived value reflects the judgment about whether the travel is economically reasonable by comparing the utility they obtain with the cost-in terms of money and time-they pay for the destination [60,61]. Therefore, perceived value is the comprehensive embodiment of economic cost, time cost, material benefit, and spiritual benefit [62-67]. Perceived value is not only the reflection of tourists' value judgment of the destination image, but also an 
important precondition for whether they are willing to visit again and recommend the destination to others. It serves as an important mediating variable between tourists' psychological perception, rational analysis, and behavioral intention [68,69].

\subsection{Behavioral Intention}

Tourist behavioral intention is the probability judgment of making travel decisions in the future $[70,71]$. Behavioral intention, as the prelude to travel behavior, is closely related to the actual conduct that also has an impact on the tourist's future revisiting rate, loyalty, and word of mouth [1,72]. Tourist behavioral intention is mostly measured in three dimensions: revisit intention, willingness to travel at a premium, and recommendation intention [73-75]. How to increase tourists' willingness to visit a certain destination has become important for destination marketing. Therefore, the study of tourist behavioral intention is of great practical significance for the innovative marketing and management of destinations [72,76].

\subsection{Perceived Safety, Perceived Image, and Trust}

Tourists' perceived safety determines their trust in the destination. The higher the level of perceived safety, the higher the level of trust $[77,78]$. Hence, perceived safety often has a significantly positive impact on tourists' trust in destinations [79-82]. Regarding the relationship between perceived image and destination trust, a large number of studies have confirmed the positive promotional effect of perceived image on destination trust [41,83-85]. Tourists comprehensively evaluate the resource facilities, environment, service, and other aspects of the destination, thus forming a certain sense of destination trust [82]. Therefore, the following hypotheses are proposed:

Hypothesis 2 (H2). Tourists' perceived safety of Southern Xinjiang has a positive impact on their trust in Southern Xinjiang. That is to say, the safer tourists believe Southern Xinjiang to be, the higher their trust.

Hypothesis 3 (H3). Tourists' perceived image of Southern Xinjiang positively impacts their trust in Southern Xinjiang. That is to say, the better the tourist evaluation of Southern Xinjiang, the higher their trust.

\subsection{Perceived Safety, Perceived Image, Trust, and Perceived Value}

Some papers have shown that the lower the tourists' perceived safety, the higher their perceived risk, and the lower the return due to tourism, hence lowering the sense of value of a given destination [86-88]. Therefore, tourists' perceived safety may affect their value judgment of the destination. Scholars fully proved the significant influence of perceived image on perceived value in research on the relationship between these factors [88-90]. Tourists' perceived image of a destination often affects the final decision indirectly through the perception of value and quality. A better image improves their sense of value [91-93]. In addition, numerous papers have verified the positive effect of trust on perceived value $[94,95]$. Tourists who have a higher sense of trust in the destination tend to provide a better evaluation of the destination [96]. Therefore, the following hypotheses are proposed:

Hypothesis 4 (H4). Tourists' perceived safety of Southern Xinjiang has a significant positive impact on their perceived value. That is to say, the safer Southern Xinjiang, the higher their sense of value.

Hypothesis 5 (H5). Tourists' perceived image of Southern Xinjiang has a significant positive influence on their perceived value. The higher tourists' image evaluation of Southern Xinjiang, the higher their sense of value.

Hypothesis 6 (H6). Tourists' trust of Southern Xinjiang has a significant positive impact on their perceived value. The more tourists trust Southern Xinjiang, the higher their sense of value. 


\subsection{Trust, Perceived Value, and Behavioral Intention}

In many papers, trust has been proven to have a significant positive effect on tourist behavioral intention [54,97]. Trust can produce a public praise effect of the destination, and then affect tourists' intentions in terms of recommendation and revisiting [76,98]. In papers on the relationship between perceived value and tourist behavioral intention, several scholars confirmed that perceived value has a significant positive influence on behavioral intention [99-103].

Therefore, the following hypotheses are proposed:

Hypothesis 7 (H7). Tourists' trust of Southern Xinjiang has a significant positive influence on their travel intention. The more tourists trust Southern Xinjiang, the stronger their intention to travel there.

Hypothesis $\mathbf{8}$ (H8). Tourists' perceived value of Southern Xinjiang has a significant positive impact on their travel intention. The higher tourists' sense of value, the stronger their intention to visit Southern Xinjiang.

In summary, the study framework is shown in Figure 1.

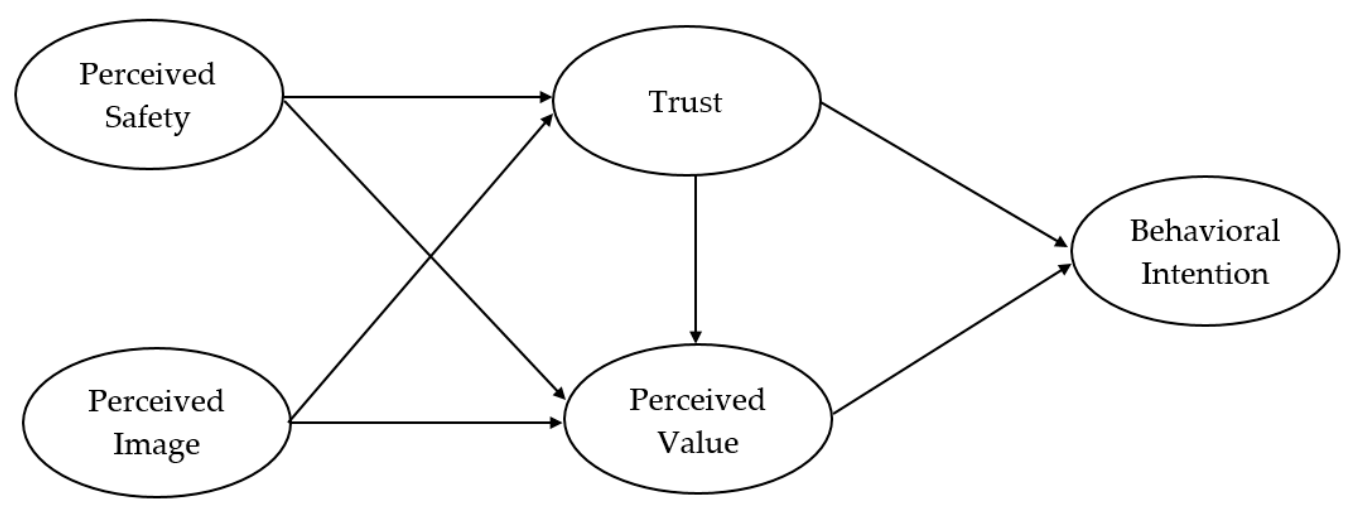

Figure 1. Study framework.

\section{Methodology}

\subsection{Study Area}

In this paper, Southern Xinjiang was chosen as the study area, which is characterized by abundant tourism resources, unique geographical location, and diversified ethnic composition; additionally, the safety situation is considered bad. As the source of Uygur culture, there are many cultural tourist areas, such as Kashgar Ancient City, Id Kah Mosque (the largest mosque in China), Xiangfei Tomb, and Thousand Buddha Cave, and natural tourist attractions such as Bayanbulak Grassland, Taklimakan Desert, Muztagh Ata, and Desert Oasis. The China National Tourism Administration has proposed building Southern Xinjiang into a tourist destination of Silk Road Culture and Folk Custom. Southern Xinjiang includes Kashi Prefecture, Hotan Prefecture, Kergez Autonomous Prefecture of Kizilsu, and Aksu Prefecture, covering 1,080,000 km². The area of Southern Xinjiang, accounting for two-thirds of the total area of Xinjiang province, is 2.5 times as large as that of Northern Xinjiang. Southern Xinjiang lies on the northwestern border of China, bordering six countries, including Kyrgyzstan, Pakistan, and Tajikistan. The ethnic composition of Southern Xinjiang is diverse. Southern Xinjiang has always been a multi-ethnic area, consisting of several ethnic groups with different customs, such as the Uygur ethnic group, the Tajik nationality, and Kirgiz nationality. Southern Xinjiang has always been considered unsafe by tourists from other regions of China. Affected by the 5 July 2009 terrorist attacks and the Shache County Terrorist Attacks in 2014, Xinjiang has long been considered an unsafe destination. The primary source of the main participants of most violent terrorist attacks are people from Southern Xinjiang, where the economic situation is relatively poor. Also, the distance between Southern and Northern Xinjiang is quite large. Most people in Northern Xinjiang, who may never 
have been to Southern Xinjiang, tend to think that unsafe incidents only happen in the south. Even though many precautionary measures have been adopted and there have been no massive terrorist attacks since 2014, people from other regions are still worried about the safety situation. The unsafe image seems very difficult to shake. As such, choosing Southern Xinjiang as the study area has both theoretical and practical significance.

\subsection{Questionnaire Design}

The questionnaire in this study included two parts: a five-point Likert scale, ranging from "strongly disagree" (1) to "strongly agree" (5), was adopted to measure perceived safety, perceived image, trust, perceived value, and behavioral intention. The second part covered the demographic information of the respondents.

In the first part, the measurement items of each variable were adapted according to the mature scale used by prior scholars. After consulting several scholars in the field of tourism research in Southern Xinjiang, the questionnaire was modified according to their feedback. Therefore, the questionnaire had good content validity. Before the investigation, the study team interviewed many scholars, officials, tourism practitioners, community residents, and tourists in Southern Xinjiang from 20 August to 5 September 2015.

The practical situation of Southern Xinjiang was preliminarily determined. Then, the study team collected scales from papers to measure the variables. A pre-survey questionnaire was formed after discussion with relevant scholars. The team went to Southern Xinjiang once again to issue the questionnaires for pre-survey from 25 September to 8 October 2016. A total of 100 pre-survey questionnaires were issued and 82 valid questionnaires were recovered, with an effective recovery rate of $82 \%$. The content of the questionnaire was fine-tuned according to the pre-survey. Then, the final questionnaire was formed after being reviewed by relevant scholars. Finally, the study team issued the final questionnaire from 22 June to 5 October 2017.

The first part included 19 items. Three items measured perceived safety, which are adapted from previous studies [104-106]. The items were as follows. PS1: I am concerned about the safety situation in Southern Xinjiang. PS2: Considering the safety situation, I think it is a bad decision to travel to Southern Xinjiang. PS3: The social public security of Southern Xinjiang is good. There were 5 items to measure perceived image, which were adapted from the scales in prior studies $[41,48,107]$. The contents are as follows. EI1: I think Southern Xinjiang is a pleasant place. EI2: I think Southern Xinjiang is an exciting place. EI3: I think Southern Xinjiang is a relaxing place. EI4: I think Southern Xinjiang is an unforgettable place. EI5: I do not think a trip to Southern Xinjiang would be boring. There were 3 items to measure trust, which were adapted from the scale used by Delgado-Ballester [108] and Han et al. [109]: TR1: I have confidence in Southern Xinjiang's tourism resources, TR2: I think it is a good idea to travel to Southern Xinjiang, and TR3: I think the problems encountered can be solved when traveling to Southern Xinjiang. There were 5 items measuring perceived value, which were adapted from the scale used by Buhalis [66] and Boo et al. [110]: PV1: I think the prices in Southern Xinjiang are reasonable. PV2: I think a trip to Southern Xinjiang gives good value for money. PV3: I think the cost of traveling to Southern Xinjiang is relatively low. PV4: I think it is very economical to travel to Southern Xinjiang. PV5: I think it is a good idea to travel to Southern Xinjiang. There were 3 items to measure behavioral intention, which were adapted from the scale used by Parasuraman et al. [72] and Assaker et al. [73]. The contents were as follows. BI1: I would recommend traveling to Southern Xinjiang to my friends or relatives. BI2: If there is a chance, I would like to travel to Southern Xinjiang again. BI3: I am willing to pay more for a trip to Southern Xinjiang.

The second part included 7 items, I1-I7. I1: Have you traveled to Southern Xinjiang in the past three years? I2: In which city do you live? I3: What is your sex? I4: What is your highest educational degree? I5: How old are you? I6: What is your occupation? I7: What is your monthly income range? 


\subsection{Sampling}

The final questionnaire was issued by 3 professors and 7 graduate students from 22 June to 5 October 2017. In order to ensure random sampling, the questionnaires were randomly issued in multiple locations utilizing a convenient sampling method. The respondents were divided into 4 groups: tourists in Southern Xinjiang (group 1), tourists with experience of traveling to Southern Xinjiang (group 2), non-Xinjiang tourists without experience in Southern Xinjiang (group 3), and Northern Xinjiang tourists without experience of traveling to Southern Xinjiang (group 4). As for group 1, the questionnaires were issued in Kashgar Ancient City, Id Kah Mosque, the youth hostel, Kashgar airport, and Hotan Prefecture in Southern Xinjiang. For groups 2 and 3, the questionnaires were issued in Jinan, Beijing, $\mathrm{Xi}^{\prime}$ an, Lanzhou, and Urumuqi. For group 4, the questionnaires were issued in Northern Xinjiang, including Urumuqi, Turpan, and Hami. Any personal preference was avoided when filling in the questionnaires. In addition, some reverse questions were set to eliminate unqualified questionnaires. Finally, the respondents who completed the questionnaire would receive a souvenir. In total, 1250 questionnaires were issued and 1019 valid questionnaires were recovered, an overall effective recovery rate of $81.5 \%$. In group 1 , a total of 400 questionnaires were issued and 318 valid questionnaires were recovered, a recovery rate of $79.5 \%$. In group 2, a total of 300 questionnaires were issued and 261 valid questionnaires were recovered, a valid recovery rate of $87.0 \%$. In group 3 , a total of 300 questionnaires were distributed and 232 valid questionnaires were recovered, a recovery rate of $77.3 \%$. In group 4, a total of 250 questionnaires were distributed and 208 effective questionnaires were recovered, a valid recovery rate of $83.2 \%$. In general, the number of samples collected should be 10 times more than the number of observed variables contained in the model to establish an effective structural equation model [111]. Loehlin proposed that robust estimation results can be obtained when the number of samples is greater than 200 [112]. Therefore, the number of samples obtained in this study satisfied the research needs. The specific compositions of the samples are shown in Table 1.

Table 1. Descriptive statistics.

\begin{tabular}{|c|c|c|c|c|c|c|}
\hline Variable & \multicolumn{6}{|c|}{ Number (Percent) } \\
\hline Sex & \multicolumn{3}{|c|}{$\begin{array}{c}\text { Male } \\
544(53.4 \%)\end{array}$} & \multicolumn{3}{|c|}{$\begin{array}{c}\text { Female } \\
475(46.6 \%)\end{array}$} \\
\hline Education & $\begin{array}{l}\text { High school } \\
\text { or below }\end{array}$ & \multicolumn{2}{|c|}{ Junior college } & Bachelor & \multicolumn{2}{|c|}{ Master or above } \\
\hline & $249,24.4 \%$ & 276 & $7.1 \%$ & $355,34.8 \%$ & \multicolumn{2}{|c|}{$139,13.6 \%$} \\
\hline Career & $\begin{array}{c}\text { Student } \\
241,23.7 \% \\
\end{array}$ & $\begin{array}{l}\text { Teacher } \\
85,8.3 \%\end{array}$ & \multicolumn{2}{|c|}{$\begin{array}{c}\text { Entrepreneur } \\
77,7.6 \%\end{array}$} & $\begin{array}{c}\text { Civil servant } \\
59,5.8 \%\end{array}$ & $\begin{array}{c}\text { Others } \\
557,54.7 \%\end{array}$ \\
\hline $\begin{array}{l}\text { Monthly Income } \\
\text { (yuan) }\end{array}$ & $\begin{array}{l}3000 \text { or less } \\
327,32.1 \%\end{array}$ & $\begin{array}{l}3001-5000 \\
249,24.4 \%\end{array}$ & \multicolumn{2}{|c|}{$\begin{array}{l}5001-8000 \\
180,17.7 \%\end{array}$} & $\begin{array}{c}8001-10,000 \\
117,11.5 \%\end{array}$ & $\begin{array}{c}10,000 \text { or above } \\
146,14.3 \%\end{array}$ \\
\hline Age & $\begin{array}{c}18 \text { or below } \\
72,7.1 \%\end{array}$ & $\begin{array}{c}19-24 \\
225,22.1 \%\end{array}$ & $\begin{array}{c}25-35 \\
391,38.4 \%\end{array}$ & $\begin{array}{c}36-45 \\
145,14.2 \%\end{array}$ & $\begin{array}{c}46-60 \\
127,12.5 \%\end{array}$ & $\begin{array}{c}60 \text { or above } \\
59,5.8 \%\end{array}$ \\
\hline Place of Residence & $\begin{array}{l}\text { Xinjiang } \\
289,28.4 \%\end{array}$ & $\begin{array}{c}\text { Beijing } \\
159,15.6 \%\end{array}$ & $\begin{array}{c}\text { Guangdong } \\
118,11.6 \%\end{array}$ & $\begin{array}{c}\text { Shandong } \\
82,8.0 \%\end{array}$ & $\begin{array}{l}\text { Shanghai } \\
74,7.3 \%\end{array}$ & $\begin{array}{c}\text { others } \\
297,29.1 \%\end{array}$ \\
\hline
\end{tabular}

\section{Results}

\subsection{Analysis of Normality and Common Method Bias}

We analyzed the normality of the data through the kurtosis and skewness test in order to test whether the obtained data were distributed normally. The results show that there was no outlier, indicating that the data were distributed normally. In order to avoid common method bias, we tested several methods including Harman's single factor test, partial correlation method, and the multi-trait-multimethod model $[113,114]$. All the results showed that there was no common method bias in the data, meaning the data were suitable for further analysis. 


\subsection{Exploratory Factor Analysis}

Although the measured items in this study were all from mature scales, the applicability should be further tested in order to be scientific. Kolar and Zabkar [115] proposed testing the validity of data through exploratory factor analysis. In this study, the principal component method was adopted for all the data to perform factor rotation. The final results are shown in Table 2. The factor loading values of all items were greater than 0.6 after factor rotation, and the items for each variable were all gathered together (see the bold figures in Table 2), indicating that the data had good construct validity. Based on this, exploratory factor analysis was also carried out for the four groups of data. The results showed that the data for each group had good construct validity.

Table 2. Exploratory factor analysis matrix of the whole data.

\begin{tabular}{cccccc}
\hline Indicators & $\begin{array}{c}\text { Perceived } \\
\text { Safety }\end{array}$ & $\begin{array}{c}\text { Perceived } \\
\text { Image }\end{array}$ & Trust & $\begin{array}{c}\text { Perceived } \\
\text { Value }\end{array}$ & $\begin{array}{c}\text { Behavioral } \\
\text { Intention }\end{array}$ \\
\hline PS1 & -0.023 & 0.045 & $\mathbf{0 . 9 0 8}$ & 0.049 & 0.028 \\
PS2 & -0.047 & 0.051 & $\mathbf{0 . 9 3 4}$ & 0.040 & 0.058 \\
PS3 & -0.021 & 0.078 & $\mathbf{0 . 9 0 5}$ & 0.054 & 0.020 \\
PI1 & $\mathbf{0 . 8 1 5}$ & 0.185 & -0.006 & 0.187 & 0.117 \\
PI2 & $\mathbf{0 . 8 2 5}$ & 0.170 & -0.004 & 0.142 & 0.172 \\
PI3 & $\mathbf{0 . 8 0 9}$ & 0.162 & -0.052 & 0.169 & 0.143 \\
PI4 & $\mathbf{0 . 7 8 8}$ & 0.182 & -0.029 & 0.104 & 0.201 \\
PI5 & $\mathbf{0 . 7 4 1}$ & 0.256 & -0.029 & 0.107 & 0.153 \\
TR1 & 0.207 & 0.276 & 0.069 & $\mathbf{0 . 7 7 1}$ & 0.223 \\
TR2 & 0.198 & 0.229 & 0.016 & $\mathbf{0 . 8 5 3}$ & 0.138 \\
TR3 & 0.195 & 0.238 & 0.097 & $\mathbf{0 . 8 1 4}$ & 0.178 \\
PV1 & 0.185 & $\mathbf{0 . 7 8 6}$ & 0.037 & 0.208 & 0.154 \\
PV2 & 0.213 & $\mathbf{0 . 7 5 1}$ & 0.052 & 0.225 & 0.252 \\
PV3 & 0.219 & $\mathbf{0 . 8 3 3}$ & 0.040 & 0.123 & 0.174 \\
PV4 & 0.167 & $\mathbf{0 . 8 3 9}$ & 0.056 & 0.138 & 0.118 \\
PV5 & 0.267 & $\mathbf{0 . 6 9 2}$ & 0.094 & 0.272 & 0.205 \\
BI1 & 0.380 & 0.274 & 0.076 & 0.196 & $\mathbf{0 . 7 0 5}$ \\
BI2 & 0.352 & 0.210 & 0.011 & 0.214 & $\mathbf{0 . 7 3 4}$ \\
BI3 & 0.131 & 0.304 & 0.060 & 0.190 & $\mathbf{0 . 7 5 9}$ \\
\hline
\end{tabular}

\subsection{Reliability and Validity Analysis}

In this paper, Cronbach's $\alpha$ was adopted for the reliability test. The results showed that the coefficients of Cronbach's $\alpha$ for each variable in the overall data and four groups were all greater than 0.7 (Table 3, grouping results are detailed in Tables A1-A4), indicating good data consistency, and showing the data met the requirements for further analysis.

In the validity analysis, composite reliability (CR) and average variance extracted (AVE) were used to test the convergent validity and discrimination validity. In the test of convergent validity, Table 3 and the Tables A1-A4 show that the standardized factor loading values were all greater than the standard value 0.6 , the CR values were all greater than 0.7 , and the AVE values were all greater than 0.5 , which conforms to the standards proposed by Hair et al. [116]. In the test of discrimination validity, Fornell and Larcker [117] stated that if the root mean square of the AVE value of a variable is greater than its correlation coefficients with other variables, the variable has good discrimination validity. As shown in Table 4, the discrimination validity of each variable confirms the criterion in the four groups. 
Table 3. Reliability and convergent validity of overall data.

\begin{tabular}{|c|c|c|c|c|c|c|c|}
\hline Variable & Indicators & SFL & S.E. & $T$ Value & CR & Cronbach' $\alpha$ & AVE \\
\hline \multirow{3}{*}{ Perceived Safety } & PS1 & 0.827 & & & \multirow{3}{*}{0.892} & \multirow{3}{*}{0.891} & \multirow{3}{*}{0.735} \\
\hline & PS2 & 0.922 & 0.037 & $32.794^{* * *}$ & & & \\
\hline & PS3 & 0.819 & 0.035 & $30.128^{* * *}$ & & & \\
\hline \multirow{5}{*}{ Perceived Image } & PI1 & 0.836 & & & \multirow{5}{*}{0.898} & \multirow{5}{*}{0.897} & \multirow{5}{*}{0.638} \\
\hline & PI2 & 0.837 & 0.033 & $31.524 * * *$ & & & \\
\hline & PI3 & 0.797 & 0.035 & $29.403^{* * *}$ & & & \\
\hline & PI4 & 0.774 & 0.035 & $28.177^{* * *}$ & & & \\
\hline & PI5 & 0.746 & 0.034 & $26.776^{* * *}$ & & & \\
\hline \multirow{3}{*}{ Trust } & TR1 & 0.807 & & & \multirow{3}{*}{0.861} & \multirow{3}{*}{0.861} & \multirow{3}{*}{0.674} \\
\hline & TR2 & 0.839 & 0.039 & $28.147^{* * *}$ & & & \\
\hline & TR3 & 0.816 & 0.039 & $27.419 * * *$ & & & \\
\hline \multirow{5}{*}{ Perceived Value } & PV1 & 0.782 & & & \multirow{5}{*}{0.898} & \multirow{5}{*}{0.898} & \multirow{5}{*}{0.636} \\
\hline & PV2 & 0.820 & 0.040 & $28.056^{* * *}$ & & & \\
\hline & PV3 & 0.831 & 0.041 & $28.496^{* * *}$ & & & \\
\hline & PV4 & 0.775 & 0.041 & $26.198 * * *$ & & & \\
\hline & PV5 & 0.778 & 0.040 & $26.329 * * *$ & & & \\
\hline \multirow{3}{*}{ Behavioral Intention } & BI1 & 0.851 & & & \multirow{3}{*}{0.811} & \multirow{3}{*}{0.809} & \multirow{3}{*}{0.598} \\
\hline & BI2 & 0.769 & 0.037 & $25.352 * * *$ & & & \\
\hline & BI3 & 0.691 & 0.037 & $22.557 * * *$ & & & \\
\hline
\end{tabular}

Note: SLF is standard factor loading, SE is standard error, ${ }^{* * *}$ means $p<0.001$.

Table 4. Discrimination validity.

\begin{tabular}{|c|c|c|c|c|c|c|c|c|c|c|c|c|}
\hline Variable & No. & PS & PI & TR & PV & BI & No. & PS & PI & TR & PV & BI \\
\hline PS & & 0.874 & & & & & & 0.873 & & & & \\
\hline PI & & 0.147 & 0.819 & & & & & 0.065 & 0.806 & & & \\
\hline $\mathrm{TR}$ & Group 1 & 0.428 & 0.500 & 0.855 & & & Group 2 & 0.218 & 0.540 & 0.851 & & \\
\hline PV & & 0.266 & 0.545 & 0.597 & 0.851 & & & 0.144 & 0.566 & 0.644 & 0.797 & \\
\hline BI & & 0.351 & 0.728 & 0.636 & 0.684 & 0.818 & & 0.141 & 0.695 & 0.626 & 0.674 & 0.768 \\
\hline Mean & & 3.56 & 3.91 & 3.84 & 3.63 & 3.53 & & 3.36 & 3.94 & 3.66 & 3.77 & 3.89 \\
\hline S.D. & & 1.12 & 0.79 & 0.88 & 0.90 & 0.84 & & 1.14 & 0.75 & 0.82 & 0.80 & 0.82 \\
\hline PS & & 0.807 & & & & & & 0.778 & & & & \\
\hline PI & & -0.462 & 0.794 & & & & & -0.450 & 0.793 & & & \\
\hline TR & Group 3 & -0.383 & 0.538 & 0.800 & & & Group 4 & -0.442 & 0.464 & 0.813 & & \\
\hline PV & & -0.280 & 0.557 & 0.667 & 0.774 & & & -0.303 & 0.574 & 0.519 & 0.756 & \\
\hline BI & & -0.371 & 0.638 & 0.605 & 0.689 & 0.757 & & -0.326 & 0.607 & 0.587 & 0.624 & 0.752 \\
\hline Mean & & 2.53 & 3.81 & 3.40 & 3.35 & 3.60 & & 2.15 & 3.83 & 3.33 & 3.43 & 3.61 \\
\hline S.D. & & 0.90 & 0.72 & 0.76 & 0.71 & 0.80 & & 0.79 & 0.73 & 0.80 & 0.67 & 0.81 \\
\hline
\end{tabular}

Note: The value on the diagonal represents the root mean square of AVE, and the correlation coefficients between variables are below the diagonal.

\subsection{Model Fit Analysis}

In this study, the AMOS17.0 (International Business Machines Corporation, New York, NY, USA) was used to test the model fit in the four groups. The results are shown in Table 5, which demonstrates that all the indicators met the criteria, except that GFI was slightly lower than 0.9. Therefore, from a comprehensive view, the fit of the four models was sufficiently good for further analysis.

Table 5. Model fit analysis.

\begin{tabular}{cccccccccc}
\hline Indicators & CMIN/DF & GFI & RMR & RMSEA & IFI & CFI & TLI & PNFI & PCFI \\
\hline Group 1 & 2.342 & 0.901 & 0.065 & 0.065 & 0.957 & 0.957 & 0.949 & 0.781 & 0.806 \\
Group 2 & 2.780 & 0.853 & 0.055 & 0.079 & 0.923 & 0.922 & 0.908 & 0.745 & 0.777 \\
Group 3 & 2.244 & 0.870 & 0.057 & 0.073 & 0.929 & 0.928 & 0.915 & 0.740 & 0.782 \\
Group 4 & 2.211 & 0.862 & 0.047 & 0.076 & 0.919 & 0.918 & 0.903 & 0.726 & 0.773 \\
Criterion & $<3$ & $>0.9$ & $<0.08$ & $<0.08$ & $>0.9$ & $>0.9$ & $>0.9$ & $>0.5$ & $>0.5$ \\
\hline
\end{tabular}




\subsection{Comparing Means Analysis}

In this study, SPSS 22.0 (International Business Machines Corporation, New York, NY, USA) was used to test the difference between the means of perceived safety in the four groups. Group 2 was set as the base group, and groups 1,3, and 4 were the control groups. The specific results are shown in the Table 6 . The difference in the mean value of perceived safety between groups 1 and 2 was $-0.20(p=0.030)$, which indicates that the mean value of perceived safety by group 2 was significantly smaller than that of group 1 . The difference in the mean value of perceived safety between groups 2 and 3 was $0.83(p=0.000)$, which indicates that the mean value of perceived safety by group 2 was significantly greater than that of group 3 . The difference in the mean value of the perceived safety between groups 2 and 4 was $1.21(p=0.000)$, which indicates that the mean value of the perceived safety by group 2 was significantly greater than that of group 4 . These results illustrate that tourists in Southern Xinjiang and tourists with experience of traveling to Southern Xinjiang have higher safety perceptions than those without experience, thus supporting H1.

Table 6. Comparing means of perceived safety.

\begin{tabular}{cccccc}
\hline Variable & Classification & No. & Mean & T Value & $p$ \\
\hline \multirow{4}{*}{ Perceived Safety } & Base Group & 2 & 3.36 & - & - \\
\cline { 2 - 6 } & & 1 & 3.56 & -2.171 & 0.030 \\
& \multirow{2}{*}{ Control Group } & 3 & 2.53 & 8.798 & 0.000 \\
& & 4 & 2.15 & 12.979 & 0.000 \\
\hline
\end{tabular}

\subsection{Path Analysis}

The results of path analysis are shown in Table 7. The standardized path coefficients between perceived safety and trust were $0.365,0.183,-0.171$, and -0.288 in M1-M4, respectively $(p=0.000$, $0.002,0.029$, and 0.000 , respectively). In groups 1 and 2, the tourists' perceived safety of Southern Xinjiang had a significant positive effect on their trust of Southern Xinjiang. In groups 3 and 4 , the tourists' perceived safety of Southern Xinjiang had a significantly negative influence on their trust of Southern Xinjiang. Hence, the results partly support $\mathrm{H} 2$. The standardized path coefficients between perceived image and trust were $0.469,0.543,0.476$, and 0.349 in M1-M4 with $p=0.000, p=0.000$, $p=0.000$, and $p=0.000$, respectively, which indicates that the tourists' perceived image has a significant positive effect on their trust. Hence, the results support $\mathrm{H} 3$. The standardized path coefficients between the perceived safety and the perceived value were $0.048,0.023,0.055$, and 0.041 with $p=0.380, p=0.673$, $p=0.430$, and $p=0.616$, for in M1-M4, respectively, which indicates that the tourists' perceived safety did not have a significant effect on their sense of value. Hence, the results do not support H4. The standardized path coefficients between perceived image and perceived value were $0.348,0.332,0.319$, and 0.457 in M1-M4, with $p=0.000, p=0.000, p=0.000$, and $p=0.000$, respectively, which indicates that the tourists' perceived safety has a significant effect on their sense of value. Hence, the results support H5. The standardized path coefficients between trust and perceived value were $0.395,0.455$, 0.513 , and 0.319 in M1-M4, with $p=0.000, p=0.000, p=0.000$, and $p=0.000$, respectively, which indicates that tourists' trust in Southern Xinjiang has a significant positive effect on their sense of value. Hence, the results support H6. The standardized path coefficients between trust and behavioral intention were $0.375,0.335,0.279$, and 0.360 in M1-M4, respectively, $p=0.000, p=0.000, p=0.002$, and $p=0.000$, respectively, which indicates that tourists' trust in Southern Xinjiang has a significant positive effect on their willingness to travel there. Hence, the results support H7. The standardized path coefficients between perceived value and behavioral intention were $0.473,0.485,0.520$, and 0.457 in M1-M4, respectively, with $p=0.000, p=0.000, p=0.000$, and $p=0.000$, respectively, which indicates that tourists' perceived value of traveling to Southern Xinjiang has a significant positive effect on their willingness to travel there. Hence, the results support H8. 
Table 7. Path analysis.

\begin{tabular}{|c|c|c|c|c|c|c|c|c|c|c|c|c|}
\hline \multirow{2}{*}{$\begin{array}{c}\text { Group } \\
\text { Path }\end{array}$} & \multicolumn{3}{|c|}{ M1 } & \multicolumn{3}{|c|}{ M2 } & \multicolumn{3}{|c|}{ M3 } & \multicolumn{3}{|c|}{ M4 } \\
\hline & $\begin{array}{c}\text { Standardized } \\
\text { Coefficient }\end{array}$ & $\begin{array}{l}\text { Standard } \\
\text { Error }\end{array}$ & $p$ & $\begin{array}{c}\text { Standardized } \\
\text { Coefficient }\end{array}$ & $\begin{array}{l}\text { Standard } \\
\text { Error }\end{array}$ & $p$ & $\begin{array}{c}\text { Standardized } \\
\text { Coefficient }\end{array}$ & $\begin{array}{l}\text { Standard } \\
\text { Error }\end{array}$ & $p$ & $\begin{array}{c}\text { Standardized } \\
\text { Coefficient }\end{array}$ & $\begin{array}{l}\text { Standard } \\
\text { Error }\end{array}$ & $p$ \\
\hline $\mathrm{PS} \rightarrow \mathrm{TR}$ & 0.365 & 0.040 & $* * *$ & 0.183 & 0.043 & 0.002 & -0.171 & 0.068 & 0.029 & -0.288 & 0.088 & $* * *$ \\
\hline $\mathrm{PI} \rightarrow \mathrm{TR}$ & 0.469 & 0.058 & $* * *$ & 0.543 & 0.066 & $* * *$ & 0.476 & 0.079 & $* * *$ & 0.349 & 0.088 & $* * *$ \\
\hline $\mathrm{PS} \rightarrow \mathrm{PV}$ & 0.048 & 0.049 & 0.380 & 0.023 & 0.039 & 0.673 & 0.055 & 0.053 & 0.430 & 0.041 & 0.061 & 0.616 \\
\hline $\mathrm{PI} \rightarrow \mathrm{PV}$ & 0.348 & 0.075 & $* * *$ & 0.332 & 0.071 & $* * *$ & 0.319 & 0.067 & $* * *$ & 0.457 & 0.068 & $* * *$ \\
\hline $\mathrm{TR} \rightarrow \mathrm{PV}$ & 0.395 & 0.084 & $* * *$ & 0.455 & 0.073 & $* * *$ & 0.513 & 0.076 & $* * *$ & 0.319 & 0.064 & $* * *$ \\
\hline $\mathrm{TR} \rightarrow \mathrm{BI}$ & 0.375 & 0.076 & $* * *$ & 0.335 & 0.079 & $* * *$ & 0.279 & 0.112 & 0.002 & 0.360 & 0.090 & $* * *$ \\
\hline $\mathrm{PV} \rightarrow \mathrm{BI}$ & 0.473 & 0.063 & $* * *$ & 0.485 & 0.084 & $* * *$ & 0.520 & 0.133 & $* * *$ & 0.457 & 0.126 & $* * *$ \\
\hline
\end{tabular}

Note: ${ }^{* * *}$ means $p<0.001$. 


\subsection{Multiple Group Comparison}

According to the results of path analysis, the tourists' perceived safety of Southern Xinjiang positively affected their trust in Southern Xinjiang in groups 1 and 2, whereas the tourists' perceived safety of Southern Xinjiang negatively affected their trust in Southern Xinjiang in groups 3 and 4 . This result contradicts the hypothesis. In order to further test whether the differences in the path coefficients were significant, multiple group comparison was used, selecting group 2 as the benchmark. The final results are shown in Table 8. The difference was significant when comparing the standardized path coefficient between perceived safety and trust in group 2 with that in other groups $(p=0.000, p=0.000$, and $p=0.000$, in groups 1,3 , and 4 , respectively). The coefficients of groups 1 and 2 were positive, while the coefficients of groups 3 and 4 were negative.

Table 8. Multiple group comparison.

\begin{tabular}{cccccccc}
\hline Path & Group & Standardized Coefficient & Difference Value & DF & CMIN & NFI & $p$ \\
\hline \multirow{4}{*}{ PS $\rightarrow$ TR } & 1 & 0.36 & - & - & - & - & - \\
& 2 & 0.18 & 0.18 & 1 & 313.194 & 0.038 & 0.000 \\
& 3 & -0.17 & 0.35 & 1 & 258.048 & 0.035 & 0.000 \\
& 4 & -0.29 & 0.65 & 1 & 245.450 & 0.035 & 0.000 \\
\hline
\end{tabular}

\section{Discussion}

\subsection{Paradox of Safety Perception Exists in Southern Xinjiang}

We found a paradox in the safety perception of Southern Xinjiang. According to previous theory, tourists' trust in the destination increases with the improvement in tourists' perceived safety $[79,82]$. This theory was confirmed again by the results of groups 1 and 2 . That is to say, the path coefficient between perceived safety and trust was significantly positive. However, in groups 3 and 4, this coefficient was significant but negative, which contradicts previous theory. Why would this happen? We think that these results were caused by the phenomenon of the paradox of safety perception. Tourists' attitudes toward the safety situation of the destination differ. Tourists are optimistic when they have a higher sense of safety. The safer the destination, the more trustful the tourist. Tourists are very cautious when they feel less secure. Even if there is information that indicates that the safety situation of the destination has improved, tourists' trust does not immediately increase. Conversely, it may have an inhibitory effect. Overly cautious tourists may think that such information may appear to cover up insecurity, since safety is the bottom line for them.

This phenomenon can also be partly explained by trust asymmetry theory [118]. The trust damage caused by negative information is much greater than the trust repair caused by positive information. This asymmetry degree lasts for a long time [119] and is difficult to mitigate [120].

A surprising result was that the absolute value of the coefficient between perceived safety and trust in group 4 was larger than that in group 3. The asymmetry degree in tourists from Northern Xinjiang without experience in Southern Xinjiang was even larger than that in tourists from other provinces without experience in Southern Xinjiang.

Public security in Southern Xinjiang has always been good. The China National Tourism Administration has never issued a notice of safety risks for Southern Xinjiang, with very few violent incidents happening. Simultaneously, the security in Southern Xinjiang is excellent after the implementation of increasing security and other measures. The tourists in Southern Xinjiang or those with experience in Southern Xinjiang have an accurate understanding of the security situation through their own experiences, positively evaluating the safety situation. However, for non-Xinjiang tourists and Northern Xinjiang tourists without experience in Southern Xinjiang, they have no first-hand experience of the security situation. For the sake of caution, the government's propaganda of "Xinjiang is safe" and "Southern Xinjiang is safe" instead causes distrust. Tourists also think the government may conceal the fact that Southern Xinjiang is unsafe. For Northern Xinjiang tourists without experience in 
Southern Xinjiang, they know very little about the security situation in the south. Meanwhile, their sense of distrust is stronger than that of others because they have been perplexed by the long-term and ceaseless provision of propaganda providing slogans like "Xinjiang is safe" for such a long time.

\subsection{Perceived Safety between Tourists with or without Experience in Southern Xinjiang Differs Significantly}

This result is consistent with previous studies $[29,30]$. Tourists in Southern Xinjiang or those with experience in the area have a positive perception of the region's safety. The two groups of tourists evaluated the security situation in Southern Xinjiang with a score of at least three (out of five). This result is the true reflection of the security situation in Southern Xinjiang. In comparison, tourists without experience have a negative perception. The two groups rated the area less than three on average for the safety situation. Tourists without experience have a cognitive bias, which indicates that the security situation in Southern Xinjiang has been stigmatized. The very few violent incidents in the past have had extremely serious impacts that have been magnified by the phenomenon of media panic. The whole of Xinjiang is experiencing an unreal security situation. The residents in Northern Xinjiang believe that Northern Xinjiang is very safe. However, people from other provinces have misunderstood the security situation in Xinjiang. Although they know little about the real security situation in Southern Xinjiang because of the distance, with more than $1000 \mathrm{~km}$ between the north and the south, they only distrust Southern Xinjiang. From the perspective of attribution theory, participation would affect the result of attribution [121], which partly explains why Northern Xinjiang tourists have the greatest cognitive bias. This result shows that although they all live in Xinjiang, communication between them is not sufficient. Therefore, strengthening the all-around communication between the two areas may be an effective measure to solve this problem.

\subsection{Destination Image Plays a Key Role in Tourists' Decision-Making}

Destination image is still decisive in influencing tourists' decision-making. The results showed that tourists' perceived image positively affects their trust and perceived value, which then affects tourists' travel intention. This finding is consistent with the research results of Artigas [82] and Lin [93]. The path coefficient between perceived image and trust is greater than that between perceived safety and trust. Also, the path coefficient between perceived image and perceived value is greater than that between perceived safety and perceived value, except in group 1, where the two values were nearly equivalent. This shows that perceived image plays a key role in the decision-making in all cases. This also means that the quality of tourism resources is still very important for Southern Xinjiang.

\subsection{Difference in the Mechanism of Perceived Safety and Perceived Image on Tourist Behavioral Intention}

The results show that perceived safety affects tourist behavioral intention only through the mediating effect of trust, whereas trust and perceived value play mediating roles between perceived image and tourist behavioral intention. This indicates that the mechanism of safety and image on tourists' travel decision differ. Safety affects tourists' sense of trust but does not directly provide value. Image can influence both trust and value. This sheds light on the importance of the management of safety and image of Southern Xinjiang in the future.

\section{Conclusions and Implications}

\subsection{Conclusions}

We explored the mechanisms of tourists' perceived safety and perceived image on their decisions to travel to Southern Xinjiang. The final conclusions were obtained via normality analysis, common method bias analysis, exploratory factor analysis, reliability testing, validity testing, model fit analysis, comparing means, path analysis, and multiple group comparison. We found that the paradox of safety perception exists in tourists' perception of Southern Xinjiang. Tourists with experience in Southern Xinjiang provide a better safety evaluation than those tourists without such experience. Tourists 
without experience in Southern Xinjiang have a cognitive bias, which results in stigmatization of the security situation in Southern Xinjiang. Destination image is still decisive in influencing tourists' decision-making. Thus, image marketing is still very important. The mechanisms of safety and image on tourists' travel decision are different. The findings in this paper provide enlightening insights for the further development of tourism marketing activities in Southern Xinjiang.

\subsection{Theoretical Implications}

We found that there exists the phenomenon of a paradox of safety perception in Southern Xinjiang which supplements the existing tourism safety theory. Safety is the basic guarantee for the sustainable development of the destination and a requirement for tourists' decision-making. Too much emphasis on safety may be counterproductive on the tourism propaganda aimed at potential tourists without experience in Southern Xinjiang. It sheds light on avoiding cognitive bias for the destinations. Meanwhile, safety was regarded as a dimension of perceived image in some papers. However, the findings in this paper illustrate the difference in the mechanism of perceived safety and perceived image on tourist behavioral intention. It expands the dimension of perceived image.

\subsection{Practical Implications}

In the future, for tourists without experience in Southern Xinjiang, the government should focus on highlighting the value of tourism resources, while reducing safety slogans. Marketing activities should focus on folk customs instead of safety. For the tourists in Southern Xinjiang, the government could promote both safety and the value of resources. Strengthening the integration of tourism resources, providing high-quality services for tourists, and improving their satisfaction are still effective means for maintaining sustainable development. In addition, image publicity and value marketing are still important for Southern Xinjiang, suggesting that destinations similar to Southern Xinjiang with safety cognitive biases should adopt effective measures to improve their own value. Encouraging tourists to share their experiences on social media, holding tourism promotion meetings centered on Xinjiang culture, strengthening the all-around communication between Southern Xinjiang and other regions, and building a new tourism brand with the characteristics of silk road culture and folk custom, are all effective measures.

\subsection{Limitations and Further Research}

There are some shortcomings in this paper. Firstly, we adopted the convenient sampling method in this paper because Southern Xinjiang is more than 1,080,000 $\mathrm{km}^{2}$. Hence, the findings need further verification. Secondly, we focused on the mechanism of perceive safety and perceived image, and more effective and practical measures should be proposed in further research. Thirdly, specific strategies for Southern Xinjiang to build a new tourism brand should be explored in future research.

Author Contributions: F.X. and S.L. designed the research, analyzed the data, and drafted the manuscript; S.L. and X.L. modified the manuscript; F.X., S.L., X.L. and W.N. carried out the field work and collected the data.

Funding: This research was funded by NSSFC, grant number 15BMZ052.

Acknowledgments: The authors are very grateful to the friends from all walks of life who met with us in Southern Xinjiang, and who cooperated with our research. Colleagues and graduate students who have traveled to Xinjiang to do the research many times made much-appreciated contributions to this work.

Conflicts of Interest: The authors declare no conflict of interest. 


\section{Appendix A}

Table A1. Reliability and convergent validity (Group 1).

\begin{tabular}{|c|c|c|c|c|c|c|c|}
\hline Variable & Indicators & SFL & S.E. & $T$ Value & C.R. & Cronbach' $\alpha$ & AVE \\
\hline \multirow{3}{*}{ Perceived safety } & PS1 & 0.838 & & & \multirow{3}{*}{0.906} & \multirow{3}{*}{0.904} & \multirow{3}{*}{0.763} \\
\hline & PS2 & 0.927 & 0.059 & $20.024^{* * *}$ & & & \\
\hline & PS3 & 0.853 & 0.059 & $18.496^{* * *}$ & & & \\
\hline \multirow{5}{*}{ Perceived image } & PI1 & 0.820 & & & \multirow{5}{*}{0.911} & \multirow{5}{*}{0.910} & \multirow{5}{*}{0.671} \\
\hline & PI2 & 0.849 & 0.061 & $17.755^{* * *}$ & & & \\
\hline & PI3 & 0.844 & 0.063 & $17.594^{* * *}$ & & & \\
\hline & PI4 & 0.831 & 0.063 & $17.205^{* * *}$ & & & \\
\hline & PI5 & 0.749 & 0.068 & $14.898^{* * *}$ & & & \\
\hline \multirow{3}{*}{ Trust } & TR1 & 0.819 & & & \multirow{3}{*}{0.891} & \multirow{3}{*}{0.891} & \multirow{3}{*}{0.731} \\
\hline & TR2 & 0.865 & 0.062 & $17.730 * * *$ & & & \\
\hline & TR3 & 0.880 & 0.066 & $18.080^{* * *}$ & & & \\
\hline \multirow{5}{*}{ Perceived value } & PV1 & 0.843 & & & \multirow{5}{*}{0.929} & \multirow{5}{*}{0.929} & \multirow{5}{*}{0.725} \\
\hline & PV2 & 0.851 & 0.053 & $19.122^{* * *}$ & & & \\
\hline & PV3 & 0.878 & 0.050 & $20.127^{* * *}$ & & & \\
\hline & PV4 & 0.884 & 0.052 & $20.367^{* * *}$ & & & \\
\hline & PV5 & 0.797 & 0.051 & $17.174^{* * *}$ & & & \\
\hline \multirow{3}{*}{ Behavioral intention } & BI1 & 0.845 & & & \multirow{3}{*}{0.857} & \multirow{3}{*}{0.854} & \multirow{3}{*}{0.668} \\
\hline & $\mathrm{BI} 2$ & 0.870 & 0.056 & $17.595^{* * *}$ & & & \\
\hline & BI3 & 0.731 & 0.059 & $14.292 * * *$ & & & \\
\hline
\end{tabular}

Table A2. Reliability and convergent validity.

\begin{tabular}{|c|c|c|c|c|c|c|c|}
\hline Variable & Indicators & SFL & S.E. & $T$ Value & C.R. & Cronbach' $\alpha$ & AVE \\
\hline \multirow{3}{*}{ Perceived safety } & PS1 & 0.870 & & & \multirow{3}{*}{0.905} & \multirow{3}{*}{0.903} & \multirow{3}{*}{0.762} \\
\hline & PS2 & 0.933 & 0.062 & $19.173^{* * *}$ & & & \\
\hline & PS3 & 0.812 & 0.060 & $16.432^{* * *}$ & & & \\
\hline \multirow{5}{*}{ Perceived image } & PI1 & 0.862 & & & \multirow{5}{*}{0.902} & \multirow{5}{*}{0.900} & \multirow{5}{*}{0.650} \\
\hline & PI2 & 0.833 & 0.059 & $16.658^{* * *}$ & & & \\
\hline & PI3 & 0.815 & 0.063 & $16.098^{* * *}$ & & & \\
\hline & PI4 & 0.758 & 0.068 & $14.392^{* * *}$ & & & \\
\hline & PI5 & 0.756 & 0.067 & $14.329^{* * *}$ & & & \\
\hline \multirow{3}{*}{ Trust } & TR1 & 0.886 & & & \multirow{3}{*}{0.888} & \multirow{3}{*}{0.888} & \multirow{3}{*}{0.725} \\
\hline & TR2 & 0.839 & 0.061 & $16.884^{* * *}$ & & & \\
\hline & TR3 & 0.828 & 0.063 & $16.561^{* * *}$ & & & \\
\hline \multirow{5}{*}{ Perceived value } & PV1 & 0.774 & & & \multirow{5}{*}{0.897} & \multirow{5}{*}{0.897} & \multirow{5}{*}{0.636} \\
\hline & PV2 & 0.780 & 0.080 & $13.176^{* * *}$ & & & \\
\hline & PV3 & 0.826 & 0.072 & $14.091^{* * *}$ & & & \\
\hline & PV4 & 0.795 & 0.077 & $13.475^{* * *}$ & & & \\
\hline & PV5 & 0.811 & 0.071 & $13.784^{* * *}$ & & & \\
\hline \multirow{3}{*}{ Behavioral intention } & BI1 & 0.767 & & & \multirow{3}{*}{0.810} & \multirow{3}{*}{0.808} & \multirow{3}{*}{0.590} \\
\hline & $\mathrm{BI} 2$ & 0.802 & 0.088 & $11.993^{* * *}$ & & & \\
\hline & $\mathrm{BI} 3$ & 0.734 & 0.086 & $11.143^{* * *}$ & & & \\
\hline
\end{tabular}


Table A3. Reliability and convergent validity (Group 3).

\begin{tabular}{|c|c|c|c|c|c|c|c|}
\hline Variable & Indicators & SFL & S.E. & $T$ Value & C.R. & 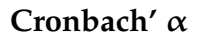 & AVE \\
\hline \multirow{3}{*}{ Perceived safety } & PS1 & 0.760 & & & \multirow{3}{*}{0.848} & \multirow{3}{*}{0.846} & \multirow{3}{*}{0.651} \\
\hline & PS2 & 0.880 & 0.101 & $12.086^{* * *}$ & & & \\
\hline & PS3 & 0.775 & 0.099 & $11.408^{* * *}$ & & & \\
\hline \multirow{5}{*}{ Perceived image } & PI1 & 0.818 & & & \multirow{5}{*}{0.895} & \multirow{5}{*}{0.894} & \multirow{5}{*}{0.631} \\
\hline & PI2 & 0.848 & 0.074 & $14.755^{* * *}$ & & & \\
\hline & PI3 & 0.788 & 0.079 & $13.393^{* * *}$ & & & \\
\hline & PI4 & 0.778 & 0.074 & $13.148^{* * *}$ & & & \\
\hline & PI5 & 0.734 & 0.074 & $12.179^{* * *}$ & & & \\
\hline \multirow{3}{*}{ Trust } & TR1 & 0.771 & & & \multirow{3}{*}{0.842} & \multirow{3}{*}{0.841} & \multirow{3}{*}{0.641} \\
\hline & TR2 & 0.831 & 0.092 & $12.284^{* * *}$ & & & \\
\hline & TR3 & 0.798 & 0.093 & $11.880^{* * *}$ & & & \\
\hline \multirow{5}{*}{ Perceived value } & PV1 & 0.749 & & & \multirow{5}{*}{0.882} & \multirow{5}{*}{0.882} & \multirow{5}{*}{0.599} \\
\hline & PV2 & 0.814 & 0.099 & $12.354^{* * *}$ & & & \\
\hline & PV3 & 0.815 & 0.107 & $12.376^{* * *}$ & & & \\
\hline & PV4 & 0.726 & 0.102 & $10.929 * * *$ & & & \\
\hline & PV5 & 0.760 & 0.103 & $11.481^{* * *}$ & & & \\
\hline \multirow{3}{*}{ Behavioral intention } & BI1 & 0.866 & & & \multirow{3}{*}{0.799} & \multirow{3}{*}{0.798} & \multirow{3}{*}{0.573} \\
\hline & BI2 & 0.735 & 0.079 & $11.253^{* * *}$ & & & \\
\hline & BI3 & 0.655 & 0.077 & $9.952^{* * *}$ & & & \\
\hline
\end{tabular}

Note: ${ }^{* * *}$ means $p<0.001$.

Table A4. Reliability and convergent validity (group 4).

\begin{tabular}{|c|c|c|c|c|c|c|c|}
\hline Variable & Indicators & SFL & S.E. & $T$ Value & C.R. & Cronbach' $\alpha$ & AVE \\
\hline \multirow{3}{*}{ Perceived safety } & PS1 & 0.767 & & & \multirow{3}{*}{0.821} & \multirow{3}{*}{0.819} & \multirow{3}{*}{0.605} \\
\hline & PS2 & 0.833 & 0.099 & $10.402^{* * *}$ & & & \\
\hline & PS3 & 0.730 & 0.095 & $9.731 * * *$ & & & \\
\hline \multirow{5}{*}{ Perceived image } & PI1 & 0.830 & & & \multirow{5}{*}{0.894} & \multirow{5}{*}{0.893} & \multirow{5}{*}{0.628} \\
\hline & PI2 & 0.837 & 0.076 & $14.008^{* * *}$ & & & \\
\hline & PI3 & 0.791 & 0.082 & $12.956^{* * *}$ & & & \\
\hline & PI4 & 0.763 & 0.078 & $12.322 * * *$ & & & \\
\hline & PI5 & 0.737 & 0.074 & $11.756^{* * *}$ & & & \\
\hline \multirow{3}{*}{ Trust } & TR1 & 0.817 & & & \multirow{3}{*}{0.854} & \multirow{3}{*}{0.852} & \multirow{3}{*}{0.661} \\
\hline & TR2 & 0.842 & 0.082 & $12.603^{* * *}$ & & & \\
\hline & TR3 & 0.778 & 0.084 & $11.722 * * *$ & & & \\
\hline \multirow{5}{*}{ Perceived value } & PV1 & 0.725 & & & \multirow{5}{*}{0.869} & \multirow{5}{*}{0.869} & \multirow{5}{*}{0.571} \\
\hline & PV2 & 0.797 & 0.110 & $10.835^{* * *}$ & & & \\
\hline & PV3 & 0.813 & 0.122 & $11.032^{* * *}$ & & & \\
\hline & PV4 & 0.715 & 0.112 & $9.741^{* * *}$ & & & \\
\hline & PV5 & 0.723 & 0.112 & $9.851^{* * *}$ & & & \\
\hline \multirow{3}{*}{ Behavioral intention } & BI1 & 0.880 & & & \multirow{3}{*}{0.793} & \multirow{3}{*}{0.792} & \multirow{3}{*}{0.565} \\
\hline & $\mathrm{BI} 2$ & 0.719 & 0.088 & $10.289^{* * *}$ & & & \\
\hline & BI3 & 0.636 & 0.085 & $9.062 * * *$ & & & \\
\hline
\end{tabular}




\section{References}

1. Lam, T.; Hsu, C.H.C. Predicting behavioral intention of choosing a travel destination. Tour. Manag. 2006, 27, 589-599. [CrossRef]

2. Fletcher, J.; Morakabati, Y. Tourism activity, terrorism and political instability within the commonwealth: The cases of Fiji and Kenya. Int. J. Tour. Res. 2008, 10, 537-556. [CrossRef]

3. Greaves, N.; Skinner, H. The importance of destination image analysis to UK rural tourism. Market. Intell. Plan. 2010, 28, 486-507. [CrossRef]

4. Quintal, V.A.; Lee, J.A.; Soutar, G.N. Risk, uncertainty and the theory of planned behavior: A tourism example. Tour. Manag. 2010, 31, 797-805. [CrossRef]

5. Choi, J.G.; Tkachenko, T.; Sil, S. On the destination image of Korea by Russian tourists. Tour. Manag. 2011, 32, 193-194. [CrossRef]

6. Guzman-Parra, V.F.; Vila-Oblitas, J.R.; Maqueda-Lafuente, J. Exploring the effects of destination image attributes on tourist satisfaction and destination loyalty: An application in Málaga, Spain. Tour. Manag. Stud. 2016, 12, 67-73. [CrossRef]

7. Cui, F.; Liu, Y.; Chang, Y.; Duan, J.; Li, J. An overview of tourism risk perception. Nat. Hazards 2016, 82, 643-658. [CrossRef]

8. Klayman, J. Varieties of confirmation bias. Psychol. Learn. Motiv. 1995, 32, 385-418.

9. Rabin, M.; Schrag, J.L. First impressions matter: A model of confirmatory bias. Q. J. Econ. 1999, 114, 37-82. [CrossRef]

10. Gentzkow, M.; Shapiro, J.M. What drives media slant? Evidence from US daily newspapers. Econometrica 2010, 78, 35-71.

11. Jeuring, J.; Becken, S. Tourists and severe weather-An exploration of the role of 'Locus of Responsibility' in protective behaviour decisions. Tour. Manag. 2013, 37, 193-202. [CrossRef]

12. Chew, E.Y.T.; Jahari, S.A. Destination image as a mediator between perceived risks and revisit intention: A case of post-disaster Japan. Tour. Manag. 2014, 40, 382-393. [CrossRef]

13. Kuto, B.; Groves, J. The effects of terrorism: Evaluating Kenyas tourism crisis. E-Rev. Tour. Res. 2004, 2, $88-95$.

14. Ch, H. Xinjiang Statistical Yearbook-2015; China Statistics Press: Beijing, China, 2015; pp. 7-8.

15. Xu, F.; Li, S.S. Destination Image of Southern Sinkiang and Tourist Intention: Mediating Effects of Perceived Value and Psychological Distance. Bus. Manag. J. 2018, 40, 156-171.

16. Huan, T.C.; Beaman, J.; Shelby, L. No-Escape Natural Disaster: Mitigating Impacts on Tourism. Ann. Tour. Res. 2004, 31, 255-273. [CrossRef]

17. Woosnam, K.M.; Shafer, C.S.; Scott, D.; Timothy, D.J. Tourists' perceived safety through emotional solidarity with residents in two Mexico-United States border regions. Tour. Manag. 2015, 46, 263-273. [CrossRef]

18. Liu, B.; Pennington-Gray, L.; Krieger, J. Tourism crisis management: Can the Extended Parallel Process Model be used to understand crisis responses in the cruise industry? Tour. Manag. 2016, 55, 310-321. [CrossRef]

19. Moon, H.; Yoon, H.J.; Han, H. The effect of airport atmospherics on satisfaction and behavioral intentions: Testing the moderating role of perceived safety. J. Travel Tour. Mark. 2017, 34, 749-763. [CrossRef]

20. George, R. Tourist's perceptions of safety and security while visiting Cape Town. Tour. Manag. 2003, 24, 575-585. [CrossRef]

21. Tasci, A.D.A.; Boylu, Y. Cultural comparison of tourists' safety perception in relation to trip satisfaction. Int. J. Tour. Res. 2010, 12, 179-192. [CrossRef]

22. Lai, I.; Hitchcock, M.; Lu, D.; Liu, Y. The Influence of Word of Mouth on Tourism Destination Choice: Tourist-Resident Relationship and Safety Perception among Mainland Chinese Tourists Visiting Macau. Sustainability 2018, 10, 2114. [CrossRef]

23. Davisberman, J.; Berman, D. Risk and Anxiety in Adventure Programming. J. Exp. Educ. 2002, 25, 305-310.

24. Lee, M.S.; Chun, S.B.; Park, C.; Suh, K.B.; Lee, C.W. Perception of Safety as a Mediator in the Relations among Service Quality, Satisfaction, and Behavioral intention at Korean Beach Sites. J. Coast. Res. 2017, 79 (Suppl. 1), 16-20. [CrossRef]

25. Sönmez, S.F.; Graefe, A.R. Determining future travel behavior from past travel experience and perceptions of risk and safety. J. Travel Res. 1998, 37, 171-177. [CrossRef] 
26. Lepp, A.; Gibson, H. Tourist roles, perceived risk and international tourism. Ann. Tour. Res. 2003, 30, 606-624. [CrossRef]

27. Amir, A.F.; Ismail, M.N.I.; See, T.P. Sustainable tourist environment: Perception of international women travelers on safety and security in Kuala Lumpur. Procedia-Soc. Behav. Sci. 2015, 168, 123-133. [CrossRef]

28. Hsu, S.C.; Lin, C.T.; Lee, C. Measuring the effect of outbound Chinese tourists travel decision-making through tourism destination image and travel safety and security. J. Inf. Optim. Sci. 2017, 38, 559-584. [CrossRef]

29. Chon, K.S. Tourism destination image modification process: Marketing implications. Tour. Manag. 1991, 12, 68-72. [CrossRef]

30. Lepp, A.; Gibson, H.; Lane, C. Image and perceived risk: A study of Uganda and its official tourism website. Tour. Manag. 2011, 32, 675-684. [CrossRef]

31. Hunt, J.D. Image as a Factor in Tourism Development. Tour. Recreat. Res. 1975, 13, 1-7. [CrossRef]

32. Echtner, C.M.; Ritchie, J.R.B. The measurement of destination image: An empirical assessment. J. Travel Res. 1993, 31, 3-13. [CrossRef]

33. Mee, L.Y.; Huei, C.T.; Chuan, S.B. Medical Tourists 'Behavioral intention in relation to Motivational Factors and Perceived Image of the Service Providers. Hum. Resour. Manag. 2018, 5, 1-16.

34. Fakeye, P.C.; Crompton, J.L. Image differences between prospective, first-time, and repeat visitors to the lower Rio Grande Valley. J. Travel Res. 1991, 30, 10-16. [CrossRef]

35. Baloglu, S.; Mccleary, K.W. U.S. international pleasure travelers' images of four Mediterranean destinations: A comparison of visitors and nonvisitors. J. Travel Res. 1999, 38, 144-152. [CrossRef]

36. Zhang, H.; Fu, X.; Cai, L.A.; Lu, L. Destination image and tourist loyalty: A meta-analysis. Tour. Manag. 2014, 40, 213-223. [CrossRef]

37. Papadimitriou, D.; Kaplanidou, K.; Apostolopoulou, A. Destination image components and word-of-mouth intentions in urban tourism: A multigroup approach. J. Hosp. Tour. Res. 2018, 42, 503-527. [CrossRef]

38. Smith, C.A.; Ellsworth, P.C. Patterns of cognitive appraisal in emotion. J. Pers. Soc. Psychol. 1985, 48, 813-838. [CrossRef] [PubMed]

39. Žabkar, V.; Brenčič, M.M.; Dmitrović, T. Modelling perceived quality, visitor satisfaction and behavioural intentions at the destination level. Tour. Manag. 2010, 31, 537-546. [CrossRef]

40. Bornhorst, T.; Ritchie, J.R.B.; Sheehan, L. Determinants of tourism success for DMOs \& destinations: An empirical examination of stakeholders' perspectives. Tour. Manag. 2010, 31, 572-589.

41. Chen, C.F.; Phou, S. A closer look at destination: Image, personality, relationship and loyalty. Tour. Manag. 2013, 36, 269-278. [CrossRef]

42. Castro, C.B.; Armario, E.M.; Ruiz, D.M. The influence of market heterogeneity on the relationship between a destination's image and tourists' future behaviour. Tour. Manag. 2007, 28, 175-187. [CrossRef]

43. Pike, S. Destination image analysis-A review of 142 papers from 1973 to 2000. Tour. Manag. 2002, 23, 541-549. [CrossRef]

44. Mak, A.H.N. Online destination image: Comparing national tourism organisation's and tourists' perspectives. Tour. Manag. 2017, 60, 280-297. [CrossRef]

45. Baloglu, S. Image variations of Turkey by familiarity index: Informational and experiential dimensions. Tour. Manag. 2001, 22, 127-133. [CrossRef]

46. Beerli, A.; Martin, J.D. Factors influencing destination image. Ann. Tour. Res. 2004, 31, 657-681. [CrossRef]

47. Kim, S.B.; Kwon, K.J. Examining the Relationships of Image and Attitude on Visit Intention to Korea among Tanzanian College Students: The Moderating Effect of Familiarity. Sustainability 2018, 10, 360. [CrossRef]

48. Hong, S.K.; Kim, J.H.; Jang, H.; Lee, S. The roles of categorization, affective image and constraints on destination choice: An application of the NMNL model. Tour. Manag. 2006, 27, 750-761. [CrossRef]

49. Stylidis, D.; Shani, A.; Belhassen, Y. Testing an integrated destination image model across residents and tourists. Tour. Manag. 2017, 58, 184-195. [CrossRef]

50. Mayer, R.C.; Davis, J.H.; Schoorman, F.D. An integrative model of organizational trust. Acad. Manag. Rev. 1995, 20, 709-734. [CrossRef]

51. Rousseau, D.M.; Sitkin, S.B.; Burt, R.S.; Camerer, C. Introduction to Special Topic Forum: Not so Different after All: A Cross-Discipline View of Trust. Acad. Manag. Rev. 1998, 23, 393-404. [CrossRef]

52. Hoffman, D.L.; Novak, T.P.; Peralta, M. Building consumer trust online. Commun. ACM 1999, 42, 80-85. [CrossRef] 
53. Ouyang, Z.; Gursoy, D.; Sharma, B. Role of trust, emotions and event attachment on residents' attitudes toward tourism. Tour. Manag. 2017, 63, 426-438. [CrossRef]

54. Abubakar, A.M.; Ilkan, M. Impact of online WOM on destination trust and intention to travel: A medical tourism perspective. J. Dest. Market. Manag. 2016, 5, 192-201. [CrossRef]

55. Ponnapureddy, S.; Priskin, J.; Ohnmacht, T.; Vinzenz, F.; Wirth, W. The influence of trust perceptions on German tourists' intention to book a sustainable hotel: A new approach to analysing marketing information. J. Sustain. Tour. 2017, 25, 970-988. [CrossRef]

56. Zeithaml, V.A. Consumer perceptions of price, quality, and value: A means-end model and synthesis of evidence. J. Market. 1988, 52, 2-22. [CrossRef]

57. Brady, M.K.; Cronin, J.J., Jr. Some new thoughts on conceptualizing perceived service quality: A hierarchical approach. J. Market. 2001, 65, 34-49. [CrossRef]

58. Eggert, A.; Ulaga, W. Customer perceived value: A substitute for satisfaction in business markets? J. Bus. Ind. Market. 2002, 17, 107-118. [CrossRef]

59. Martina, G.G.; Irene, G.S. Value dimensions, perceived value, satisfaction and loyalty: An investigation of university students' travel behaviors. Tour. Manag. 2006, 27, 437-452.

60. Prebensen, N.K.; Xie, J. Efficacy of co-creation and mastering on perceived value and satisfaction in tourists' consumption. Tour. Manag. 2017, 60, 166-176. [CrossRef]

61. Nambisan, S.; Baron, R.A. Different roles, different strokes: Organizing virtual customer environments to promote two types of customer contributions. Organ. Sci. 2010, 21, 554-572. [CrossRef]

62. Dodds, W.B.; Monroe, K.B.; Grewal, D. Effects of price, brand, and store information on buyers' product evaluations. J. Market. Res. 1991, 28, 307-319. [CrossRef]

63. Lassar, W.; Mittal, B.; Sharma, A. Measuring customer-based brand equity. J. Consum. Market. 1995, 12, 11-19. [CrossRef]

64. Ambler, T. How much of brand equity is explained by trust? Manag. Decis. 1997, 35, 283-292. [CrossRef]

65. Sweeney, J.C.; Soutar, G.N. Consumer perceived value: The development of a multiple item scale. J. Retail. 2001, 77, 203-220. [CrossRef]

66. Boo, S.; Busser, J.; Baloglu, S. A model of customer-based brand equity and its application to multiple destinations. Tour. Manag. 2009, 30, 219-231. [CrossRef]

67. Rasoolimanesh, S.M.; Dahalan, N.; Jaafar, M. Tourists' perceived value and satisfaction in a community-based homestay in the Lenggong Valley World Heritage Site. J. Hosp. Tour. Manag. 2016, 26, 72-81. [CrossRef]

68. Kim, J.H.; Hyun, Y.J. A model to investigate the influence of marketing-mix efforts and corporate image on brand equity in the IT software sector. Ind. Market. Manag. 2011, 40, 424-438. [CrossRef]

69. Gallarza, M.G.; Ruiz-Molina, M.E.; Gil-Saura, I. Stretching the Value-satisfaction-loyalty Chain by Adding Value Dimensions and Cognitive and Affective Satisfactions: A Causal Model for Retailing. Manag. Decis. 2016, 54, 981-1003. [CrossRef]

70. Woodside, A.G.; Lysonski, S. A general model of traveler destination choice. J. Travel Res. 1989, $27,8-14$. [CrossRef]

71. Seow, A.N.; Choong, Y.O.; Moorthy, K.; Chan, L.M. Intention to visit Malaysia for medical tourism using the antecedents of Theory of Planned Behaviour: A predictive model. Int. J. Tour. Res. 2017, 19, 383-393. [CrossRef]

72. Assaker, G.; Vinzi, V.E.; O'Connor, P. Examining the effect of novelty seeking, satisfaction, and destination image on tourists' return pattern: A two factor, non-linear latent growth model. Tour. Manag. 2011, 32, 890-901. [CrossRef]

73. Parasuraman, A.; Berry, L.L.; Zeithaml, V.A. Research note: More on improving quality measurement. J. Retail. 1993, 69, 140. [CrossRef]

74. Prayag, G.; Hosany, S.; Muskat, B.; Del Chiappa, G. Understanding the relationships between tourists' emotional experiences, perceived overall image, satisfaction, and intention to recommend. J. Travel Res. 2017, 56, 41-54. [CrossRef]

75. Kim, J.H. The impact of memorable tourism experiences on loyalty behaviors: The mediating effects of destination image and satisfaction. J. Travel Res. 2017, 57, 856-870. [CrossRef]

76. Wu, H.C.; Cheng, C.C.; Ai, C.H. A study of experiential quality, experiential value, trust, corporate reputation, experiential satisfaction and behavioral intentions for cruise tourists: The case of Hong Kong. Tour. Manag. 2018, 66, 200-220. [CrossRef] 
77. Ponte, E.B.; Carvajal-Trujillo, E.; Escobar-Rodríguez, T. Influence of trust and perceived value on the intention to purchase travel online: Integrating the effects of assurance on trust antecedents. Tour. Manag. 2015, 47, 286-302. [CrossRef]

78. Jensen, S.; Svendsen, G.T. Social Trust, Safety and the Choice of Tourist Destination. Bus. Manag. Horiz. 2016, 4. [CrossRef]

79. Chellappa, R.K.; Pavlou, P.A. Perceived information security, financial liability and consumer trust in electronic commerce transactions. Logist. Inf. Manag. 2002, 15, 358-368. [CrossRef]

80. Eitzinger, C.; Wiedemann, P.M. Trust in the safety of tourist destinations: Hard to gain, easy to lose? New insights on the asymmetry principle. Risk Anal. Int. J. 2008, 28, 843-853. [CrossRef]

81. Steele, A. Seeking safety: Avoiding displacement and choosing destinations in civil wars. J. Peace Res. 2009, 46, 419-429. [CrossRef]

82. Artigas, E.M.; Yrigoyen, C.C.; Moraga, E.T.; Villalón, C.B. Determinants of trust towards tourist destinations. J. Destin. Market. Manag. 2017, 6, 327-334.

83. Hosany, S.; Ekinci, Y.; Uysal, M. Destination image and destination personality. Int. J. Cult. Tour. Hosp. Res. 2007, 1, 62-81. [CrossRef]

84. Hsu, C.; Cai, L.A. Brand knowledge, trust and loyalty-A conceptual model of destination branding. In Proceedings of the International CHRIE Conference-Refereed Track, San Francisco, CA, USA, 29 July-1 August 2009; p. 12.

85. Wu, M.S.F. A study on the effects of word-of-mouth on brand trust in tourism industry. Eurasia J. Math. Sci Technol. Ed. 2017, 13, 7995-8002. [CrossRef]

86. Agarwal, S.; Teas, R.K. Perceived value: Mediating role of perceived risk. J. Market. Theory Pract. 2001, 9, 1-14. [CrossRef]

87. Duan, L.N.; Jung, C.H.; Park, K.H. The Effects of Perceived Risk Affecting Perceived Value and Repurchase Intention in Electronic Commerce Environment. J. Digit. Converg. 2012, 10, 13-21.

88. Yu, J.; Lee, H.; Ha, I.; Zo, H. User acceptance of media tablets: An empirical examination of perceived value. Telemat. Inform. 2017, 34, 206-223. [CrossRef]

89. Ryu, K.; Han, H.; Kim, T.H. The relationships among overall quick-casual restaurant image, perceived value, customer satisfaction, and behavioral intentions. Int. J. Hosp. Manag. 2008, 27, 459-469. [CrossRef]

90. Wu, H.C.; Li, T. A study of experiential quality, perceived value, heritage image, experiential satisfaction, and behavioral intentions for heritage tourists. J. Hosp. Tour. Res. 2017, 41, 904-944. [CrossRef]

91. Chen, C.F.; Tsai, D.C. How destination image and evaluative factors affect behavioral intentions? Tour. Manag. 2007, 28, 1115-1122. [CrossRef]

92. Wang, B.; Yang, Z.; Han, F.; Shi, H. Car Tourism in Xinjiang: The Mediation Effect of Perceived Value and Tourist Satisfaction on the Relationship between Destination Image and Loyalty. Sustainability 2016, 9, 22. [CrossRef]

93. Lin, J.S.S. The Moderating Role of Intercultural Service Encounters in the Relationship among Tourist's Destination Image, Perceived Value and Environmentally Responsible Behaviors. Am. J. Tour. Manag. 2018, 7, 1-9.

94. Chong, B.; Yang, Z.; Wong, M. Asymmetrical impact of trustworthiness attributes on trust, perceived value and purchase intention: A conceptual framework for cross-cultural study on consumer perception of online auction. In Proceedings of the 5th International Conference on Electronic Commerce, Pittsburgh, PA, USA, 30 September-3 October 2003; ACM: New York, NY, USA, 2003; pp. 213-219.

95. Lien, C.H.; Wen, M.J.; Huang, L.C.; Wu, K.L. Online hotel booking: The effects of brand image, price, trust and value on purchase intentions. Asia Pac. Manag. Rev. 2015, 20, 210-218. [CrossRef]

96. Lee, Y.K.; Kim, S.; Lee, C.K.; Kim, S.H. The impact of a mega event on visitors' attitude toward hosting destination: Using trust transfer theory. J. Travel Tour. Market. 2014, 31, 507-521. [CrossRef]

97. Kim, B.; Han, I. The role of trust belief and its antecedents in a community-driven knowledge environment. J. Assoc. Inf. Sci. Technol. 2009, 60, 1012-1026. [CrossRef]

98. Abubakar, A.M.; Ilkan, M.; Al-Tal, R.M.; Eluwole, K.K. eWOM, revisit intention, destination trust and gender. J. Hosp. Tour. Manag. 2017, 31, 220-227. [CrossRef]

99. Petrick, J.F.; Morais, D.D.; Norman, W.C. An examination of the determinants of entertainment vacationers' intentions to revisit. J. Travel Res. 2001, 40, 41-48. [CrossRef] 
100. Kwun, J.W.; Oh, H. Effects of brand, price, and risk on customers' value perceptions and behavioral intentions in the restaurant industry. J. Hosp. Leis. Market. 2004, 11, 31-49. [CrossRef]

101. Alcañiz, E.B.; García, I.S.; Blas, S.S. The functional-psychological continuum in the cognitive image of a destination: A confirmatory analysis. Tour. Manag. 2009, 30, 715-723. [CrossRef]

102. Bianchi, C.; Pike, S.; Lings, I. Investigating attitudes towards three South American destinations in an emerging long haul market using a model of consumer-based brand equity (CBBE). Tour. Manag. 2014, 42, 215-223. [CrossRef]

103. Fu, Y.; Liu, X.; Wang, Y.; Chao, R.F. How experiential consumption moderates the effects of souvenir authenticity on behavioral intention through perceived value. Tour. Manag. 2018, 69, 356-367. [CrossRef]

104. Jacoby, J.; Kaplan, L.B. The components of perceived risk. In Proceedings of the Third Annual Conference of the Association for Consumer Research, Chicago, IL, USA, 3-5 November 1972; Venkatesan, M., Ed.; pp. 382-393.

105. Lo, A.W. The three P's of total risk management. Financ. Anal. J. 1999, 55, 13-26. [CrossRef]

106. Chen, Y.S.; Chang, C.H. Greenwash and green trust: The mediation effects of green consumer confusion and green perceived risk. J. Bus. Eth. 2013, 114, 489-500. [CrossRef]

107. Baloglu, S.; Mangaloglu, M. Tourism destination images of Turkey, Egypt, Greece, and Italy as perceived by US-based tour operators and travel agents. Tour. Manag. 2001, 22, 1-9. [CrossRef]

108. Delgado-Ballester, E. Applicability of a brand trust scale across product categories: A multigroup invariance analysis. Eur. J. Market. 2004, 38, 573-592. [CrossRef]

109. Han, H.; Hyun, S.S. Customer retention in the medical tourism industry: Impact of quality, satisfaction, trust, and price reasonableness. Tour. Manag. 2015, 46, 20-29. [CrossRef]

110. Buhalis, D. Marketing the competitive destination of the future. Tour. Manag. 2000, 21, 97-116. [CrossRef]

111. Bentler, P.M.; Chou, C.P. Practical issues in structural modeling. Sociol. Methods Res. 1987, 16, 78-117. [CrossRef]

112. Loehlin, J.C. Genes and Environment in Personality Development; Sage Publications, Inc.: Thousand Oaks, CA, USA, 1992.

113. Podsakoff, P.M.; MacKenzie, S.B.; Lee, J.Y.; Podsakoff, N.P. Common method biases in behavioral research: A critical review of the literature and recommended remedies. J. Appl. Psychol. 2003, 88, 879-903. [CrossRef] [PubMed]

114. Ma, A.; Chow, A.; Cheung, L.; Lee, K.; Liu, S. Impacts of Tourists' Sociodemographic Characteristics on the Travel Motivation and Satisfaction: The Case of Protected Areas in South China. Sustainability 2018, 10, 3388. [CrossRef]

115. Kolar, T.; Zabkar, V. A consumer-based model of authenticity: An oxymoron or the foundation of cultural heritage marketing? Tour. Manag. 2010, 31, 652-664. [CrossRef]

116. Hair, J.F.; Anderson, R.E.; Tatham, R.L.; Black, W.C. Multivariate Data Analysis; Prentice Hall: Upper Saddle River, NJ, USA, 1998.

117. Fornell, C.; Larcker, D.F. Structural equation models with unobservable variables and measurement error: Algebra and statistics. J. Market. Res. 1981, 18, 382-388. [CrossRef]

118. Slovic, P. Perceived risk, trust, and democracy. Risk Anal. 1993, 13, 675-682. [CrossRef]

119. Graebner, M.E. Caveat venditor: Trust asymmetries in acquisitions of entrepreneurial firms. Acad. Manag. J. 2009, 52, 435-472. [CrossRef]

120. Bidault, F.; Castello, A. Trust and creativity: Understanding the role of trust in creativity-oriented joint developments. RED Manag. 2009, 39, 259-270.

121. Jones, E.E.; Davis, K.E. From acts to dispositions the attribution process in person perception1. Adv. Exp. Soc. Psychol. 1965, 2, 219-266.

(C) 2018 by the authors. Licensee MDPI, Basel, Switzerland. This article is an open access article distributed under the terms and conditions of the Creative Commons Attribution (CC BY) license (http:/ / creativecommons.org/licenses/by/4.0/). 